\title{
Human myiasis in rural South Africa is under-reported
}

\author{
S K Kuria, ${ }^{1} \mathrm{PhD}$; H J C Kingu, ${ }^{2} \mathrm{MD}, \mathrm{MMed}\left(\right.$ Surg); $\mathbf{M}$ H Villet, ${ }^{3} \mathrm{PhD}$; A Dhaffala, ${ }^{2} \mathrm{MB} \mathrm{ChB}, \mathrm{MMed}(\mathrm{Surg})$ \\ ${ }^{1}$ Department of Biological Sciences, Faculty of Natural Sciences, Walter Sisulu University, Mthatha, Eastern Cape, South Africa \\ ${ }^{2}$ Department of Surgery, Faculty of Health Sciences, Walter Sisulu University, Mthatha, Eastern Cape, South Africa \\ ${ }^{3}$ Department of Entomology and Zoology, Faculty of Science, Rhodes University, Grahamstown, Eastern Cape, South Africa
}

Corresponding author: S K Kuria (kkuria@wsu.ac.za)

Background. Myiasis is the infestation of live tissue of humans and other vertebrates by larvae of flies. Worldwide, myiasis of humans is seldom reported, although the trend is gradually changing in some countries. Reports of human myiasis in Africa are few. Several cases of myiasis were recently seen at the Mthatha Hospital Complex, Mthatha, Eastern Cape Province, South Africa (SA).

Objective. Because of a paucity of literature on myiasis from this region, surgeons and scientists from Walter Sisulu University, Mthatha, decided to document myiasis cases presenting either at Nelson Mandela Academic Hospital or Umtata General Hospital from May 2009 to April 2013. The objective was to determine the incidence, epidemiology, patient age group and gender, and fly species involved. The effect of season on incidence was also investigated.

Results. Twenty-five cases (14 men and 11 women) were recorded in the 4-year study period. The fly species involved were Lucilia sericata, L. cuprina, Chrysomya megacephala, C. chloropyga and Sarcophaga (Liosarcophaga) nodosa, the latter being confirmed as an agent for human myiasis for the first time. The patients were 3 - 78 years old (median 56). Cases were most numerous during spring and summer, and were associated with underlying pathologies typical of ageing.

Conclusion. Myiasis is a more common medical condition than expected in the Mthatha region. The study shows that human myiasis is still frequently encountered in SA, and there is a need to understand its epidemiology better.

S Afr Med J 2015;105(2):129-133. DOI:10.7196/SAMJ.8118

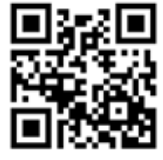

Infestation of live tissue of humans and other vertebrates by larvae (maggots) of flies is termed myiasis. The disease most commonly occurs in the tropics and subtropics. ${ }^{[1-2]}$ Clinically, human myiasis may be classified according to the location of the body invaded by maggots (ocular, nasal, oral, intestinal, etc.). ${ }^{[1-2]}$ Cutaneous myiasis may be divided further into three main types: furuncular, creeping and wound myiasis. ${ }^{[3]}$ Wound myiasis is the most prevalent type. ${ }^{[4]}$

Different fly species cause myiasis in different regions of the world. There are approximately 50 species of Diptera (mostly in the families Oestridae, Calliphoridae and Sarcophagidae) that regularly 
cause myiasis in humans. ${ }^{[1]}$ Flies of the genus Lucilia are the most common causes of myiasis. ${ }^{[1,5]}$ Cases of human myiasis have been documented from many countries in Africa, most of them caused by the blowfly Cordylobia anthropophaga (Table 1). Some of the earliest cases of myiasis reported in Africa involved livestock and larvae of the family Oestridae, with several outbreaks reported between 1920 and 1960 in South Africa (SA) and Namibia. ${ }^{[6]}$

Myiasis is usually treated by removal of the larvae and treatment of associated infections. However, some maggots are deliberately used in wound treatment, technically referred to as maggot debridement therapy. ${ }^{[7]}$ Maggots are known to benefit wounds by removing dead and necrotic tissue, secreting antimicrobial compounds and sometimes stimulating wound healing. ${ }^{[8]}$ The commonest species used for this purpose is $L$. sericata, ${ }^{[7]}$ which is distributed throughout the world, infesting humans in the Americas, Africa, Europe and Asia. ${ }^{[1,8]}$

From May 2009, surgeons working in the Mthatha Hospital Complex (MHC), Mthatha, Eastern Cape Province, SA, noted several patients presenting with cutaneous myiasis. This led to the involvement of scientists from Walter Sisulu University (WSU) and a decision to document the incidence of myiasis in the Eastern Cape, especially the Transkei region, and to identify the fly species responsible.

\section{Methods}

The study group constituted patients presenting with cutaneous myiasis and admitted between May 2009 and April
2013 to the MHC, which comprises Nelson Mandela Academic Hospital (NMAH) and Umtata General Hospital (UGH). Biodata for relevant patients were captured and included gender, age, geographical location, diagnosis and management. Examination of patients was carried out by surgeons and their diagnoses were recorded. Samples of live maggots were extracted from the wounds, which were then irrigated

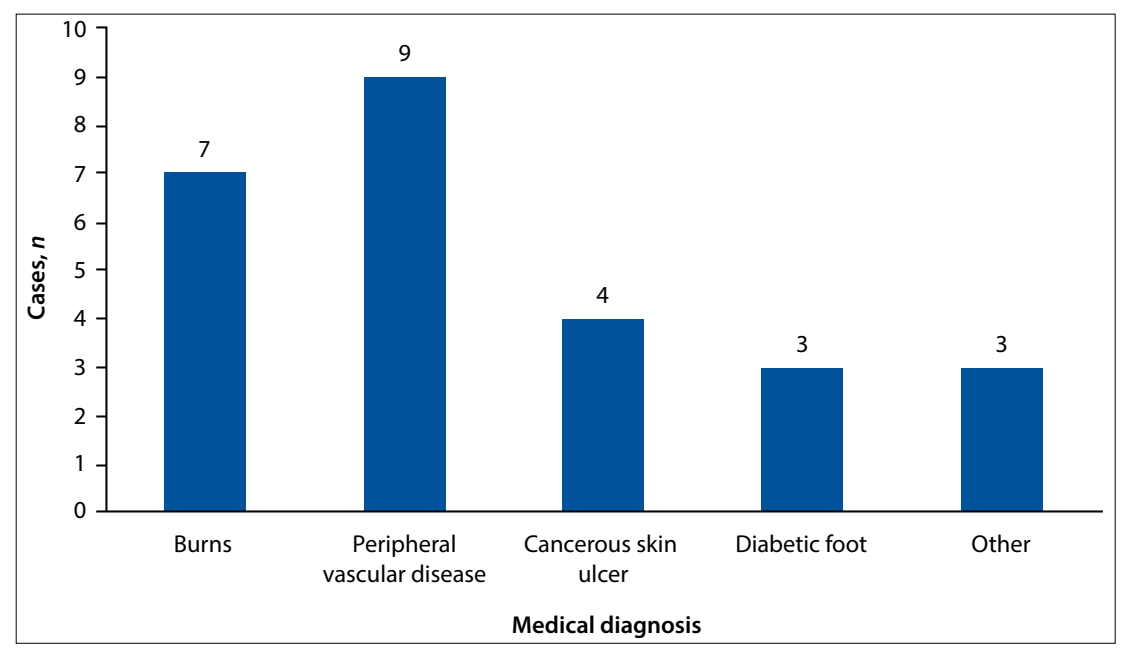

Fig. 1. Medical conditions predisposing to human myiasis.

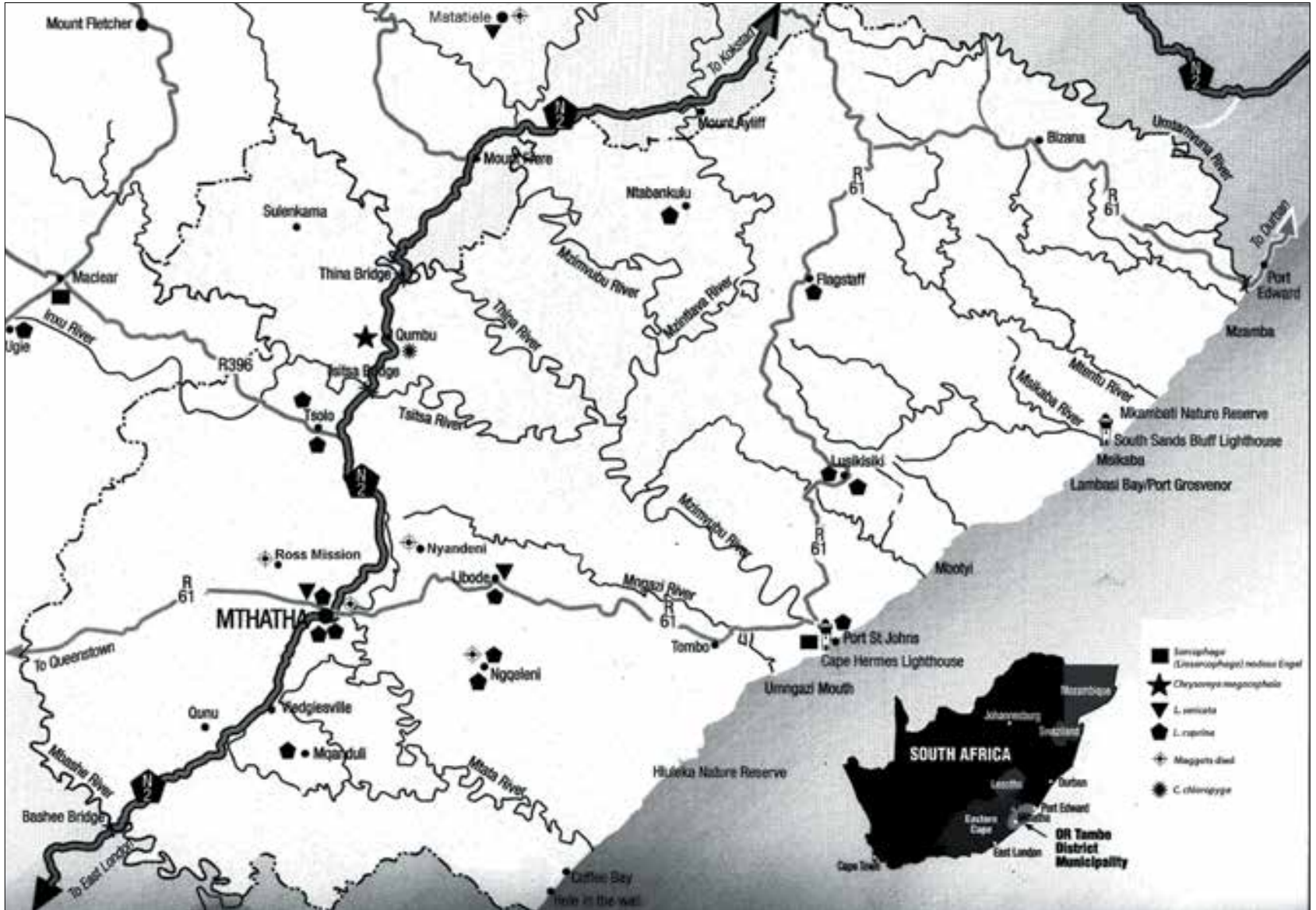

Fig. 2. Distribution of patients with myiasis, classified by associated fly species. 
with weak hydrogen peroxide to kill any remaining maggots. Subsequent treatment depended on the patient's diagnosis.

Live maggots were submitted to the WSU entomology laboratory. Since identification of fly larvae is difficult, the extracted maggots were fed on minced beef in the laboratory until they pupated. The emerging adult flies were collected and identified to species level. In a few cases, maggot samples failed to survive in the laboratory.

Since adult myiasis-causing flies are poikilothermic, their activity is affected by weather conditions (mainly temperature ${ }^{[9]}$ ). Temperature data for Mthatha were obtained from the South African Weather Service to determine the relationship of season to human myiasis.

\section{Results}

In total, 25 cases (14 men and 11 women) of cutaneous myiasis were recorded. Cases most commonly occurred in February and March, almost all in summer and autumn (Table 2). The ages of the patients ranged from 3 to 78 years (median 56) (Table 2). The most commonly diagnosed medical condition predisposing to human myiasis in this series was lower limb gangrene due to peripheral vascular disease, followed by burns, cancerous ulcers and diabetic ulcers (Fig. 1). Anatomically, lower limb infestation was the most common (Table 2).

The distribution of patients with myiasis, classified by associated fly species, is shown in Fig. 2. Five fly species were identified from the infestations: L. sericata (Meigen) $(n=3)$, L. cuprina (Wiedemann) ( $n=14)$, Chrysomya chloropyga $(n=1), C$. megacephala $(n=1)$, and Sarcophaga (Liosarcophaga) nodosa Engel $(n=2)$; in five cases the maggots died before reaching adulthood (Table 2). In two cases maggots belonging to two fly species were collected from one patient: L. cuprina and S. nodosa in one case and C. megacephala and C. chloropyga from the other.

The cases were drawn from a wide area of the Eastern Cape (Fig. 2), which is the catchment area that falls under the management of the MHC located in Mthatha. There was little difference between summer and autumn temperatures in Mthatha during the study period (Table 3). The highest temperature recorded for summer was $38.6^{\circ} \mathrm{C}$ in $2009 / 2010$ and for autumn $38.1^{\circ} \mathrm{C}$ in 2012. There were no extreme weather conditions in Mthatha (Table 3).

\section{Discussion}

Human cutaneous myiasis may be more widespread in the Eastern Cape than previously reported (Fig. 2). In 4 years
25 cases were seen, representing to our knowledge the highest number of individuals with human myiasis to be reported from SA. Owing to the paucity of literature on myiasis literature from this region, it is difficult to estimate the incidence of myiasis

in the country. The majority of cases were concentrated around NMAH and UGH, but given the widespread occurrence of the species involved, ${ }^{[1,10]}$ there is a strong possibility that cases are seen in other medical facilities in the Eastern Cape but

\section{Table 1. Cases of human myiasis reported in Africa, classified by infestation site}

\begin{tabular}{|c|c|c|c|}
\hline Type of myiasis & Species of fly & Locality & Reference \\
\hline \multirow[t]{6}{*}{ Ocular } & \multirow[t]{6}{*}{ Oestrus ovis } & Libya - Aljabal Algharbi & 15 \\
\hline & & South Africa & 16 \\
\hline & & Botswana - Kalahari Desert & 17 \\
\hline & & South Africa - Onderstepoort & 18 \\
\hline & & Zimbabwe - Gwale & 19 \\
\hline & & South Africa & 20 \\
\hline Ocular and nasal & O. ovis & Morocco & 21 \\
\hline \multirow[t]{14}{*}{ Cutaneous } & \multirow[t]{12}{*}{ Cordylobia anthropophaga } & Cameroon & 22 \\
\hline & & Congo & 23 \\
\hline & & DR Congo & 24 \\
\hline & & Namibia & 25 \\
\hline & & Nigeria - Harcourt & 26 \\
\hline & & Nigeria - Niger Delta & 27 \\
\hline & & Senegal ( 3 cases) & $28,29,30$ \\
\hline & & Sierra Leone & 31 \\
\hline & & Sudan - Gazira state & 32 \\
\hline & & The Gambia - Fajara & 33 \\
\hline & & Zimbabwe - Harare & 34 \\
\hline & & Zimbabwe - Harare & 35 \\
\hline & C. rodhaini & Ethiopia & 36 \\
\hline & Cordylobia spp. & South Africa - Pretoria & 37 \\
\hline \multirow[t]{11}{*}{ Furuncular } & \multirow[t]{10}{*}{ C. anthropophaga } & Angola & 38 \\
\hline & & East Africa & 39 \\
\hline & & Gabon & 40 \\
\hline & & Ghana & 41 \\
\hline & & Ghana - Accra & 42 \\
\hline & & Nigeria - Aba, South East & 43 \\
\hline & & Southern Africa & 39 \\
\hline & & Tanzania - Ntagatcha & 44 \\
\hline & & Uganda & 45 \\
\hline & & West Africa & 39 \\
\hline & C. rodhaini & Ghana & 46 \\
\hline \multirow[t]{2}{*}{ Gastrointestinal } & Gasterophilus sp. & Zimbabwe - Harare & 35 \\
\hline & $\begin{array}{l}\text { Sarcophaga spp. and } \\
\text { Oestrus sp. }\end{array}$ & Egypt - Minia Governorate & 47 \\
\hline Intestinal & Chrysomya chloropyga & South Africa & 48 \\
\hline Rectal & Muscina stabulans & Zimbabwe & 35 \\
\hline Urinogenital & $\begin{array}{l}\text { Sarcophaga sp. and } \\
\text { Eristalis tenax }\end{array}$ & Zimbabwe & 35 \\
\hline Sanguinivorous & Auchmeromyia luteola & $\begin{array}{l}\text { Zimbabwe - Harare, Mutare } \\
\text { and Hwange }\end{array}$ & 35 \\
\hline
\end{tabular}


Table 2. Details of patients presenting with cutaneous myiasis at the MHC

\begin{tabular}{|c|c|c|c|c|}
\hline Age (years) & Gender & Diagnosis and anatomical part involved & Maggot collection date & Fly species \\
\hline 3 & $\mathrm{~F}$ & Post skin graft, chest & 24 November 2010 & Maggots died \\
\hline 15 & M & Contracture release, neck & 19 December 2011 & Maggots died \\
\hline 19 & $\mathrm{M}$ & Donor skin, right thigh & 7 March 2011 & L. cuprina \\
\hline 22 & $\mathrm{M}$ & Burns, left knee & 5 May 2009 & S. nodosa \\
\hline 22 & M & Kaposi's sarcoma, both lower limbs & 21 February 2011 & L. cuprina \\
\hline 24 & $\mathrm{~F}$ & Gangrenous autoamputation, left foot & 4 March 2013 & L. cuprina, S. nodosa \\
\hline 34 & $\mathrm{M}$ & Biobrane dressing, facial burns & 28 March 2011 & L. cuprina \\
\hline 38 & $\mathrm{~F}$ & Ulcerative cancer, right breast & 2 April 2013 & L. cuprina \\
\hline 48 & $\mathrm{~F}$ & Burns, right hand & 20 February 2013 & L. cuprina \\
\hline 50 & $\mathrm{M}$ & Cancer, mouth floor & 29 October 2010 & L. cuprina \\
\hline 51 & $\mathrm{M}$ & Gangrene, right foot & 28 February 2011 & L. cuprina \\
\hline 54 & $\mathrm{M}$ & Diabetic ulcer, right foot & 11 March 2011 & L. cuprina \\
\hline 56 & M & $\begin{array}{l}\text { Necrotising fasciitis, penis, perineum and } \\
\text { anterior abdominal wall }\end{array}$ & 8 March 2011 (afternoon) & L. sericata \\
\hline 57 & $\mathrm{M}$ & Gangrene, right dorsum of foot & 7 May 2009 & L. cuprina \\
\hline 63 & $\mathrm{~F}$ & Diabetic ulcer, right foot & 23 May 2011 & L. cuprina \\
\hline 64 & $\mathrm{M}$ & Amputated stump, left leg & 2 March 2011 & L. cuprina \\
\hline 64 & $\mathrm{~F}$ & Burns, right foot & 12 May 2009 & Maggots died \\
\hline 66 & $\mathrm{~F}$ & Lymphoedema, left leg & 11 August 2011 & L. sericata \\
\hline 68 & $\mathrm{M}$ & Dog bite, left leg & 18 February 2011 & L. cuprina \\
\hline 70 & $\mathrm{~F}$ & Symes amputation stump, right foot & 8 March 2011 (morning) & L. sericata \\
\hline 71 & $\mathrm{M}$ & Diabetic ulcer, left foot & 21 February 2011 & L. cuprina \\
\hline 72 & $\mathrm{~F}$ & Cancerous ulcer, right leg & 3 June 2010 & C. megacephala, C. chloropyga \\
\hline 74 & $\mathrm{M}$ & Gangrene, right foot & 17 January 2012 & Maggots died \\
\hline 75 & $\mathrm{~F}$ & Gangrene, left leg & 24 April 2012 & Maggots died \\
\hline 78 & $\mathrm{~F}$ & Burns, back & 17 January 2012 & L. cuprina \\
\hline \multicolumn{5}{|c|}{$\mathrm{F}=$ female, $\mathrm{M}=$ male } \\
\hline
\end{tabular}

Table 3. Seasonal mean (standard error of the mean), minimum and maximum temperatures $\left({ }^{\circ} \mathrm{C}\right)$ obtained from the Mthatha weather station (May 2009 - May 2013) (South African Weather Service)

\begin{tabular}{|c|c|c|c|c|c|c|c|c|c|c|c|c|}
\hline \multirow[b]{3}{*}{ Year } & \multicolumn{12}{|c|}{ Seasons } \\
\hline & \multicolumn{3}{|c|}{$\begin{array}{c}\text { Summer } \\
\text { (December - February) }\end{array}$} & \multicolumn{3}{|c|}{$\begin{array}{c}\text { Autumn } \\
\text { (March - May) }\end{array}$} & \multicolumn{3}{|c|}{$\begin{array}{c}\text { Winter } \\
\text { (June - August) }\end{array}$} & \multicolumn{3}{|c|}{$\begin{array}{c}\text { Spring } \\
\text { (September - November) }\end{array}$} \\
\hline & Mean (SE) & $\mathbf{M x}$ & Mn & Mean (SE) & $\mathbf{M x}$ & Mn & Mean (SE) & $\mathbf{M x}$ & Mn & Mean (SE) & $\mathbf{M x}$ & Mn \\
\hline 2009 & & & & $21.03(0.30)$ & 36.0 & 9.9 & $14.12(0.36)$ & 31.4 & -0.9 & $17.84(0.41)$ & 37.5 & 3.5 \\
\hline $2009 / 2010$ & $22.06(0.37)$ & 38.6 & 10.9 & $19.72(0.37)$ & 36.6 & 3.2 & $14.59(0.37)$ & 36.0 & 1.1 & $18.83(0.41)$ & 38.6 & 4.8 \\
\hline $2010 / 2011$ & $21.76(0.28)$ & 35.7 & 12.2 & $18.90(0.41)$ & 35.5 & 3.2 & $12.49(0.29)$ & 34.5 & -0.1 & $17.88(0.35)$ & 39.4 & 4.0 \\
\hline $2011 / 2012$ & $22.24(0.31)$ & 37.6 & 10.8 & $18.56(0.38)$ & 38.1 & 1.7 & $13.50(0.36)$ & 35.2 & 0.3 & $16.99(0.33)$ & 35.0 & 1.8 \\
\hline $2012 / 2013$ & $21.74(0.32)$ & 37.1 & 9.4 & $18.44(0.42)$ & 37.9 & 4.3 & $14.74(0.33)$ & 35.3 & -0.2 & & & \\
\hline
\end{tabular}

are not reported. To estimate the extent of human myiasis in SA in general, there is a need to sensitise medical practitioners to document and report all human myiasis cases across the other provinces.

Several fly species are known to cause human myiasis. The commonest species in Africa is C. anthropophaga (Table 1), which does not occur in Eastern Cape because the climate is too cool. Outside the geographical distribution of C. anthropophaga, the usual causes of human myiasis worldwide are $L$. sericata and
L. cuprina. ${ }^{[1]}$ Our study has shown that $L$. cuprina is the most commonly involved species around Mthatha. C. chloropyga and C. megacephala have been reported in myiasis cases elsewhere (Table 1), so their occurrence in the Eastern Cape is not surprising. However, $S$. nodosa, previously only suspected of causing myiasis in animals, ${ }^{[1]}$ was shown to cause human myiasis for the first time only in 2009. ${ }^{[11]}$ The collection of two species from the same case is an unusual infestation that is rarely reported. ${ }^{[7]}$ All species 
are associated with decaying animal material and have wide distributions in Africa.

All the cases we recorded were cutaneous myiases. There was no obvious gender bias. Previously identified factors that predispose humans to myiasis include poverty, an immunosuppressed state, alcohol, unhygienic conditions and old age. ${ }^{[3]}$ Results suggest that debilitating diseases, especially in advanced age (the elderly being prone to infection, cancer and diabetes), predispose to cutaneous myiasis. Older patients may be more frail or sleep more than younger individuals, and may fail to fend off flies that lay their eggs in open wounds. ${ }^{[12]}$ Maintenance of cleanliness in both homes and hospitals may reduce the incidence of myiasis. There is therefore a need to educate people who care for the elderly on how to avoid or minimise fly infestations.

In the USA, it has been reported that myiasis infestations tend to occur in late summer (August - October). ${ }^{[13]}$ In the Eastern Cape the observation was different, with $52 \%$ of cases $(n=13)$ occurring in autumn (March - May) and 32\% $(n=8)$ in summer. In summer and autumn, the weather conditions recorded at Mthatha are favourable for fly activity and reproduction. However, in the current study, infestations were also reported in spring $(n=2)$ and winter $(n=2)$, before adult fly populations would have built up significantly, ${ }^{[14]}$ because the generally warmer weather conditions in Mthatha allow flies to be active throughout most of the year. ${ }^{[9]}$

Only cutaneous wound myiasis was recorded in our study, probably because the surgeons involved in the study are attached to the burns and general surgery specialties and do not see patients managed by specialties such as otorhinolaryngology or ophthalmology, who are more likely to encounter nasal or ocular myiasis, respectively.

Acknowledgements. We are grateful to Mr S Mguni for maintaining the rearing facilities. We also thank $\mathrm{Mr} S$ Swanepoel for his expert assistance in GIS and Mr G Sampson of the South African Weather Service for weather data for Mthatha. This project was funded by a research grant from WSU through the Research Directorate.

\section{References}

Zumpt FKE. Myiasis in Man and Animals in the Old World: A Textbook for Physicians, Veterinarians and Zoologists. London: Butterworths, 1965.

2. Francesconi F, Lupi O. Myiasis. Clin Microbiol Rev 2012;25(1):79-105. [http://dx.doi.org/10.1128/ CMR.00010-11]

3. Robbins K, Khachemoune A. Cutaneous myiasis: A review of the common types of myiasis. Int J Dermatol 2010;49(10):1092-1098. [http://dx.doi.org/10.1111/j.13654632.2010.04577.x]

4. Sherman RA. Wound myiasis in urban and suburban United States. Arch Intern Med 2000;160(13):20042014. [http://dx.doi.org/10.1001/archinte.160.13.2004]

5. Zumpt FKE. The problem of intestinal myiasis in humans. S Afr Med J 1963;23:305-307.

6. Basson PA. Studies on specific oculo-vascular myiasis of domestic animals (UITPEULOOG). J S Afr Vet Assoc 1962;33(13):347-349.

7. Vilcinskas A. From traditional maggot therapy to modern biosurgery. In: Vilcinskas A, ed. Insect Biotechnology. Dordrecht: Springer, 2011:67-75.

8. Service MW. Medical Entomology for Students. London: Chapman \& Hall, 2008:152-167. [http:// dx.doi.org/10.1017/CBO9780511811012]

9. Richards CS, Price BW, Villet MH. Thermal ecophysiology of seven carrion-feeding blowflies in Southern Africa. Entomol Exp Appl 2009;131(1):11-19. [http://dx.doi.org/10.1111/j.15707458.2009.00824.x

10. Richards CS, Williams KA, Villet MH. Predicting geographic distribution of seven blowfly species (Diptera: Calliphoridae) in South Africa. Afr Entomol 2009;17(2):170-182. [http://dx.doi. org/10.4001/003.017.0207]
11. Kuria SK, Kingu HJC, Vasaikar SD, et al. New fly species causing human myiasis identified in Eastern Cape, South Africa. S Afr Med J 2010;100(9):580-581.

12. Kingu HJ, Kuria SK, Villet MH, Mkhize JN, Iisa JM, Dhaffala A. Cutaneous myiasis: Is Lucilia cuprina safe and acceptable for maggot debridement therapy? Journal of Cosmetics, Dermatological Sciences and Applications 2012;2(2):79-82. [http://dx.doi.org/10.4236/jcdsa.2012.22018]

13. Delshad E, Rubin AI, Almeida L, et al. Cuterebra cutaneous myiasis: Case report and world literature review. Int I Dermatol 2008;47(4):363-366. [http://dx.doi.org/10.1111/j.1365-4632.2008.03532.x ]

14. Williams KA. Spatial and temporal occurrence of forensically important South African blowflie (Diptera: Calliphoridae). MSc thesis. Grahamstown: Rhodes University, 2003.

15. Abdellatif MZM, Elmazar HMF, Essa AB. Oestrus ovis as a cause of red eye in Aljabal Algharbi, Libya. Middle East Afr J Ophthalmol 2011;18(4):305-308. [http://dx.doi.org/10.4103/0974-9233.90133]

16. Schrire L. Conjunctival myiasis due to Oestrus ovis L. S Afr Med J 1968;42(30):765-766.

17. Rakusin W. Ocular myiasis interna caused by the sheep nasal bot fly (Oestrus ovis L.). S Afr Med $1970 ; 44(40): 1155-1157$

18. Du Toit R, Meyer H. A case in South Africa of ocular myiasis in man due to the first-stage larvae of the nasal bot fly of the sheep (Oestrus ovis L.). S Afr Med J 1960;34(28):581-582.

19. Hoffmann BL, Goldsmid JM. Ophthalmomyiasis caused by Oestrus ovis L. (Diptera: Oestridae) in Rhodesia. S Afr Med J 1979;44(22):644-645.

20. Stulting AA, Meyer H. External ophthalmomyiasis caused by Oestrus ovis. S Afr Med J 1981;60(18):709710 .

21. Smillie I, Gubbi PKS, Cocks HC. Nasal and ophthalmomyiasis: Case report. J Laryngol Oto 2010;124(8):934-935. [http://dx.doi.org/10.1017/S0022215109992714]

22. Naotunna TdeS, Ismail MM, Ihalamulla RL. The second case of cutaneous myiasis caused by Cordylobic anthropophaga (Tumbu fly) in Sri Lanka. Ceylon J Med Sci 2000;43(2):31-33.

23. Hakeem MJML, Bhattacharyya DN. Exotic human myiasis. Travel Med Infect Dis 2009;7(4):198-202. [http://dx.doi.org/10.1016/j.tmaid.2009.05.007]

24. Koźminska-Kubakska A. Cordylobia anthropophaga infestation. Int J Dermatol 1981;20(7):495-496. [http://dx.doi.org/10.1111/j.1365-4362.1981.tb04912.x]

25. Zumpt F. The Tumbu fly, Cordylobia anthropophaga (Blanchard), in southern Africa. S Afr J Med Sci 1959;33:862-865.

26. Du Toit ML. A mission doctor's experiences in West Africa. S Afr Med J 1984:66(20):775-778.

27. Ogbalu OK, Achufusi, TG, Adibe C. Incidence of multiple myiases in breasts of rural women and oral infection in infants from the human warble fly larvae in the humid Tropic-Niger Delta. Int I Dermatol 2006:45(9):1069-1070. [http://dx.doi.org/10.1111/j.1365-4632.2006.02983.x]

28. Veraldi S, Brusasco A, Süss L. Cutaneous myiasis caused by larvae of Cordylobia anthropophaga (Blanchard). Int J Dermatol 1993;32(3):184-187. [http://dx.doi.org/10.1111/j.1365-4362.1993. tb02789.x]

29. Lodi A, Bruscagin C, Gianni C, Mancini LL, Crosti C. Myiasis due to Cordylobia anthropophaga (Tumbufly). Int J Dermatol 1994;33(2):127-128. [http://dx.doi.org/10.1111/j.1365-4362.1994.tb01542.x]

30. Dalton MT, Haldane DJM. Unusual dermal arthropod infestations. Can Med Assoc J 1990;143(2):113-114

31. Muneizel S, Weshah S. Cutaneous myiasis among Jordanian soldiers in Sierra Leone. Journal of the Royal Medical Services 2003;10(1):75-77

32. Musa HA, Allah EMW. Cutaneous myiasis caused by Cordylobia anthropophaga: Description of a case from Gazira State - Sudan. Sudanese Journal of Public Health 2008;3(2):91-93.

33. Onyeama CO, Njai PC Cutaneous myiasis (Tumbu fly larvae): A case report. Niger I Paediat 2005;32(1):26-27. [http://dx.doi.org/10.4314/njp.v32i1.12097]

34. Mpofu SM. Active cutaneous myiasis: A case report. Cent Afr J Med 1984;30(8):153-154

35. Goldsmid JM, Phelps RJ. A review of myiasis of man in Rhodesia. Cent Afr J Med 1977;23(8):174-179.
36.

36. Goldsmid JM, Phelps RJ. A review of myiasis of man in Rhodesia. Cent Afr J Med 1977;23(8):174-179, from Ethiopia. Emerg Infect Dis 2011;17(12):2385-2386. [http://dx.doi.org/10.3201/eid1712.111062]
for 1 . from Ethiopia. Emerg Infect Dis 2011;17(12):2385-2386. [http://dx.doi.org/10.3201/eid1712.111062

37. Van Niekerk G, Henning M, Coetzee M. Outbreak of myiasis. S Afr Med J 2007;97(2):112-113.
38. Lee EJK, Robinson F. Furuncular myiasis of the face caused by larva of the Tumbu fly (Cordylobia anthropophaga). Eye 2007;21(2):266-268. [http://dx.doi.org/10.1038/s.eye.6702507]

39. Jelinek T, Nothduret HD, Rieder N, Löscher T. Cutaneous myiasis: Review of 13 cases in travelers returning from tropical countries. Int J Dermatol 1995;34(9):624-626. [http://dx.do org/10.1111/j.1365-4362.1995.tb01088.x]

40. Günther SH. Furuncular Tumbu-fly-myiasis of man in Gabon, Equatorial Africa. J Trop Med Hyg 1967;70(7):169-174

41. Calvert H. Myiasis from the Tumbu fly: Two cases recorded in Britain. BMJ 1961;1(5238):1513-1514. [http://dx.doi.org/10.1136/bmj.1.5238.1513]

42. Biggar RJ, Morrow H, Morrow RH. Extensive myiasis from Tumbu fly larvae in Ghana, West Africa. Clin Pediatr 1980;19(3):231-232. [http://dx.doi.org/10.1177/000992288001900311]

43. Adisa CA, Mbanaso A. Furuncular myiasis of the breast caused by the larvae of the Tumbu fly (Cordylobia anthropophaga). BMC Surg 2004;4(5):1-4. [http://www.biomedcentral.com/1471$2482 / 4 / 5$

44. Palmieri JR, North D, Santo A. Furuncular myiasis of the foot caused by the Tumbu fly, Cordylobi anthropophaga: Report in a medical student returning from a medical mission trip to Tanzania. Int Med Case Rep J 2013;6:25-28. [http://dx.doi.org/10.2147/IMCRJ.S44862]

45. Hasegawa M, Harada T, Kojima Y, et al. An imported case of furuncular myiasis due to Cordylobia anthropophaga which emerged in Japan. Br J Dermatol 2000;143(4):912-914. [http://dx.do org/10.1046/j.1365-2133.2000.03809.x]

46. Tamir J, Haik J, Schwartz E. Myiasis with Lund's fly (Cordylobia rodhaini) in travellers. J Travel Med 2003;10(5):293-295. [http://dx.doi.org/10.2310/7060.2003.2732]

47. Ahmad AK, Abdel-Hafeez EH, Makhloof M, Abdel-Raheem EM. Gastrointestinal myiasis by larvae of Sarcophaga sp. and Oestrus sp. in Egypt: Report of cases, and endoscopical and morphological studies. Korean J Parasitol 2011;49(1):51-57. [http://dx.doi.org/10.3347/kjp.2011.49.1.51]

48. De Meillon B, Osburn HS. A case of intestinal myiasis caused by the larva of Chrysomyia chloropyga Wied. (Diptera: Calliphorinae). S Afr Med J 1935;9(9):654-655.

Accepted 9 December 2014. 